\title{
EVALUATION AND DESIGN OF DOWNHOLE HEAT EXCHANGERS FOR DIRECT APPLICATION
}

\author{
950.0851 \\ Gene Culver \\ Oregon Institute of Technology \\ Klamath Falls, Oregon \\ Gordon M. Reistad \\ 4947000 \\ Oregon State University \\ Corvallis, Oregon
}

ABSTRACT

Over 400 wells with downhole heat exchangers are in use in Klamath Falls, Oregon. Some have been in use for nearly 30 years. Despite the large number and the long experience, the exact nature of the mechanism of heat exchange and, therefore, the maximum output was not known, except that it had been theorized that convection cells were established in the well. Oregon Institute of Technology and Oregon State University are jointly involved in a project to study the heat exchange process and economics of the downhole heat exchanger system.

The existence of significant convection cell circulation has been established and measured using a "spinner," hot film anemometer, and by energy balance calculations. Based on these measurements, analytical models have been developed which predict heat extraction rates within 158 of actual measured values. The existence of significant mixing of "new" and circulating well fluid has been established and can be calculated, although at this time not accurately predicted before testing a well.

Based on the analytical models, multi-tube heat exchangers have been designed and very recently tested with outputs within $15 \%$ of predicted values.

Economic analyses shows that for small to moderate extraction rates, about $300 \mathrm{KW}$ thermal, and shallow wells. DHEs may be more economical than pumped systems when surface discharge is not acceptable.

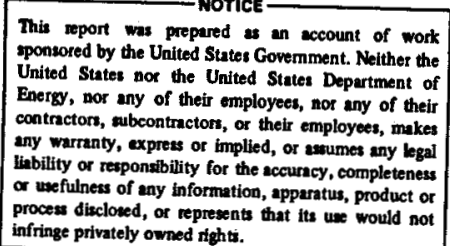




\section{DISCLAIMER}

This report was prepared as an account of work sponsored by an agency of the United States Government. Neither the United States Government nor any agency Thereof, nor any of their employees, makes any warranty, express or implied, or assumes any legal liability or responsibility for the accuracy, completeness, or usefulness of any information, apparatus, product, or process disclosed, or represents that its use would not infringe privately owned rights. Reference herein to any specific commercial product, process, or service by trade name, trademark, manufacturer, or otherwise does not necessarily constitute or imply its endorsement, recommendation, or favoring by the United States Government or any agency thereof. The views and opinions of authors expressed herein do not necessarily state or reflect those of the United States Government or any agency thereof. 


\section{DISCLAIMER}

Portions of this document may be illegible in electronic image products. Images are produced from the best available original document. 


\section{Introduction}

At the present time, over 400 downhole heat exchangers (DHEs) are being used In relatively shallow wells for extraction of geothermal energy at Klamath Falls, Oregon. Several similar designs are in use in Vale, Oregon, and over 100 of somewhat a different design in use in Reno, Nevada.

Figure 1 shows a typical Installation in Klamath Falls. It consists of (i) the wellbore, usually $26 \mathrm{~cm}$ in diameter and drilled with a cable tool rig, (ii) a casing $20 \mathrm{~cm}$ in diameter, and (iii) one or more U-shaped bare steel pipe heat exchangers.

- In Klamath Falls, well depth is determined by a sufficient section of free flowing water in one or more zones, a high temperature, and the length of DHE required to supply sufficient heat. Contractors consider $60 \mathrm{~cm}$ of free flowing strata with water near $88^{\circ} \mathrm{C}$ as the minimum to provide heat for a typical $150-$ to $170-\mathrm{m}^{2}$ home. DHE output is estimated at 8000 Joules/ min per meter of length submerged.

After drilling is completed, full depth casing is installed with slot-type perforations flame cut to coincide with free flowing hot water strata, and at just below the static water level. Cold surface water is cemented off above the perforations.

It has been known for many years that a well of this design had a heat output of several times that of a more conventional solid-cased well. Since the bore is larger than the casing and the perforations allow circulation, it was belleved that a convection cell was established within the well. Despite the large number of installations, the exact nature of the cell flows, and hence the optimal design, has not been determined.

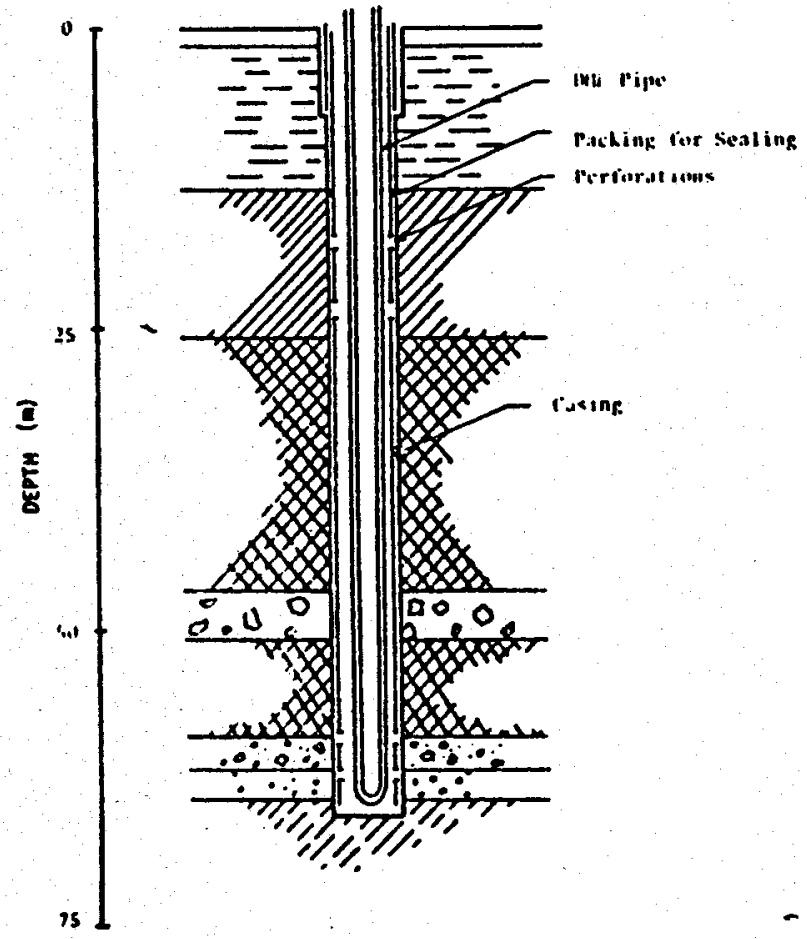

Figure 1. Downhole Heat Exchanger Installation

Standard hot water heating systems are connected in a closed loop with the DHE (see Figure 2), and the system filled with domestic water. Heat emitters may be convectors, baseboard units, radiant floor or celling panels, or more usually fan coils in forced-air systems. Gravity circulates the water in the closed loop and will provide 20.7 to $34.5 \mathrm{~K}$ Pa pressure difference in the supply and return lines to circulate 1 to $1.5 \mathrm{l} / \mathrm{sec}$ with a $5^{\circ}$ to $11^{\circ} \mathrm{C}$ temperature difference. Some larger systems or cooler wells require a small circulating pump to increase circulation rates. A separate smaller DHE at city water pressure is usually used for domestic hot water.

The largest DHE installation in Klamath Falls, supplies space heat and domestic hot water for a Junior High School. The well is $140 \mathrm{~m}$ deep, $30.5 \mathrm{~cm}$ dlameter, with $92^{\circ} \mathrm{C}$ water. Two 7.5-hp pumps circulate $33 \mathrm{l} / \mathrm{sec}$ through three $122 \mathrm{~m}$ long DHEs. The system will provide $1.03 \mathrm{M}$ W thermal.

\section{Flow Characterization}

Flow (convection cell circulation) characterization within the well has been carried out using temperature measurements, spinners, hot film anemometer, and recently fluorescent dye.

Vertical temperature profiles from several wells had indicated significant diferences between cased and uncased wells. The most useful information was 
obtained when several wells were profiled both before and after casing installation. Figure 3 shows typical profiles. The uncased profile is probably somewhat indicative of the ground temperature profile. Notice the large temperature differences (in excess of $50^{\circ} \mathrm{C}$ ) near the static water level before and after casing. Well logs show a layer of highly fractured porous basalt in the region of constant temperature in the uncased wells. The small top to bottom temperature difference after casing installation indicates large vertical water movements which keep well temperatures nearly isothermal.

Preliminary measurements of vertical flows were made using a common "spinner." The spinner is an aluminum tube about $1 \mathrm{~m}$ long and $8 \mathrm{~cm}$ in dlameter with a brass turbine inside the top and and electrical contact which provides one pulse for each revolution of the blades. The spinner is lowered into the well and turbine rotation versus time noted to obtain velocities (see Figure 4). Note the very low velocities in the uncased well. In fact, this particular well was the only one in which flows could be detected before casing installation. No flow could be measured above the top perforations with flow increasing as the perforation zone was traversed downward, remained essentially constant in the unperforated portion, and decreased as the lower perforations were traversed.

Results obtained using the spinner were useful since they indicated little or no flow in uncased wells and sizeable flows in cased wells. However, the spinner presents a significant flow restriction which will alter the natural flow in the well. Also, the spinner can be used only in open wellbores.

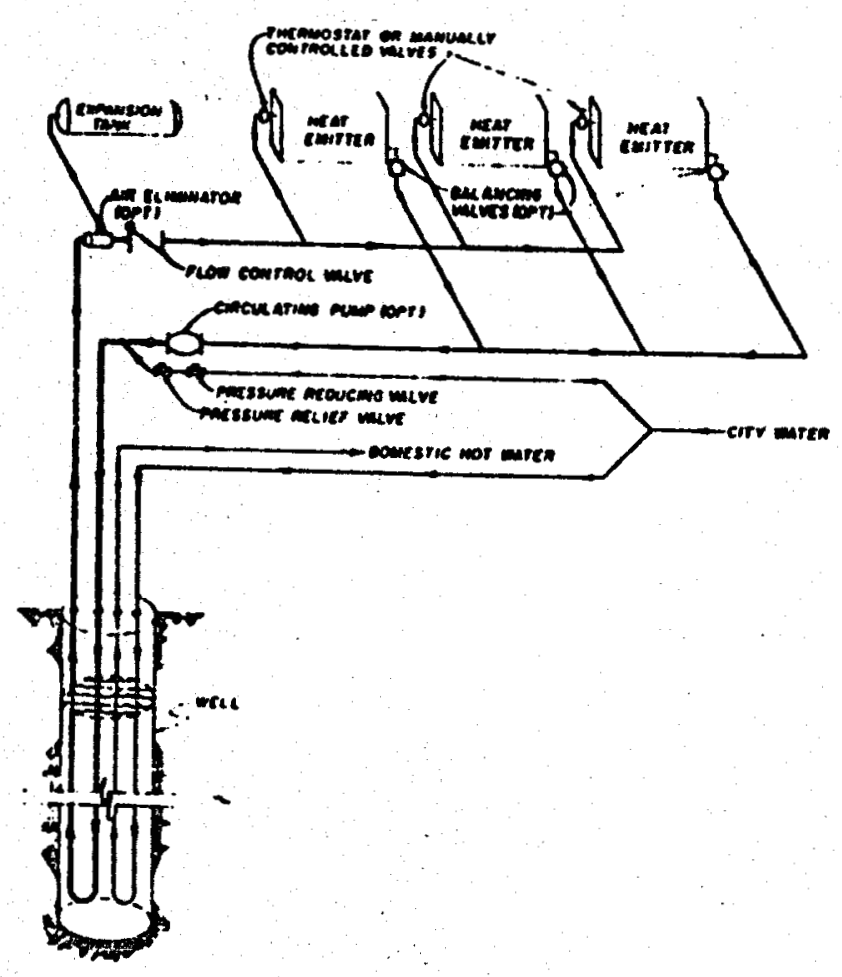

Figure 2. Typical

Hot Water Distribution System

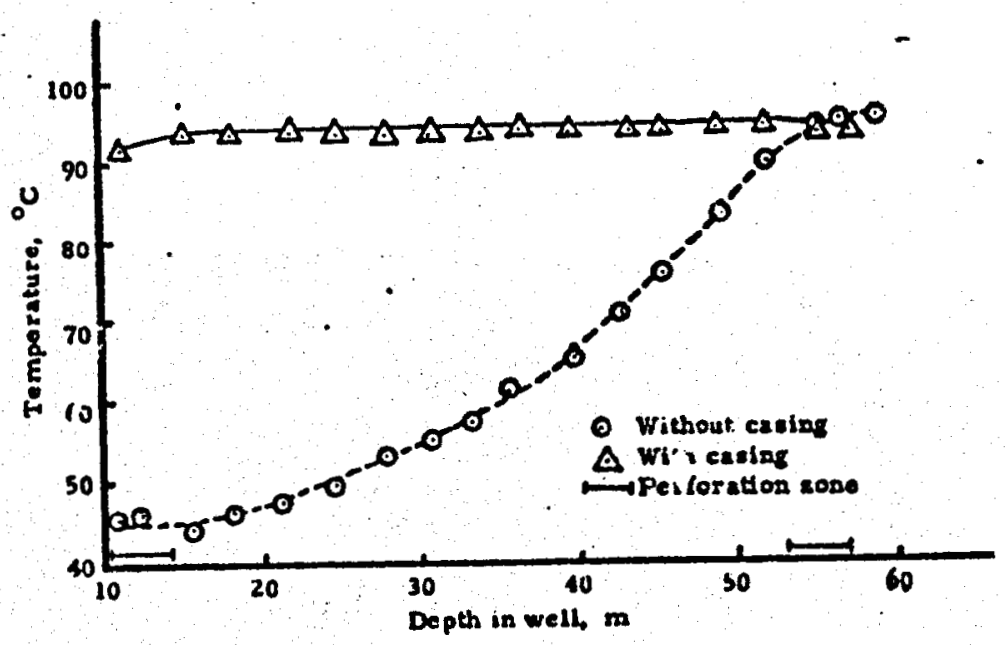

Figure 3.

Temperature vs. Depth 


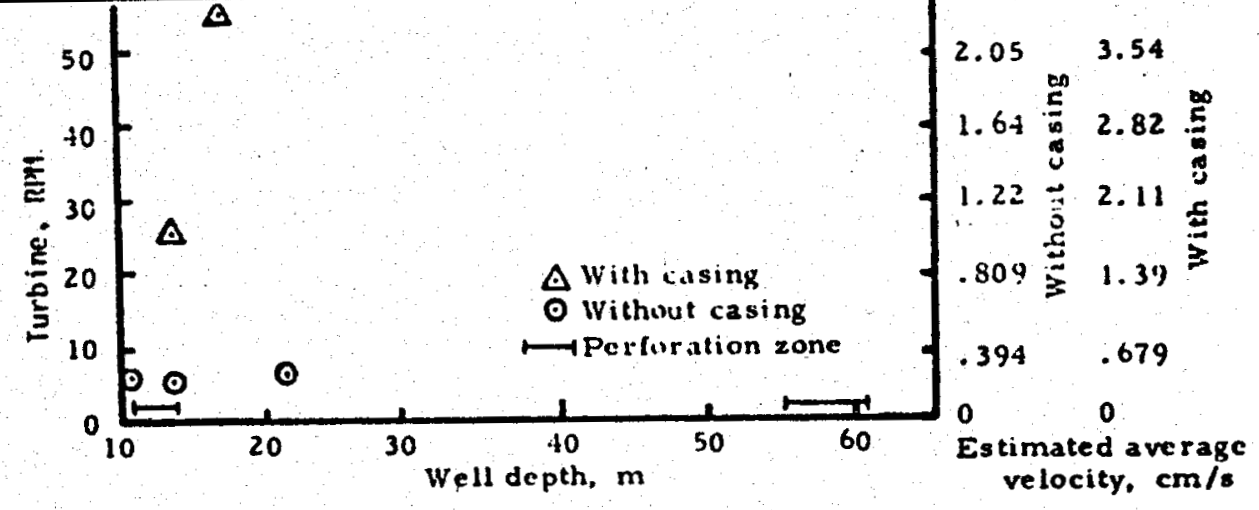

Figure 4. Vertical Velocities as Measured With Turbine Meter

A hot film anemometer (see Figure 5) was selected as one of the better devices for more accurate flow measurment. The device is small presenting little resistance to flows, can be used in wells with DHEs installed, and is relatively rugged. The probe selected has two sensors and is capable of measuring both vertical and horizontal flows. Disadvantages of the device are the limited life in water near $100^{\circ} \mathrm{C}$ due to breakdown of the epoxy sealant, a small amount of drift (probably due to fouling), and the fact that since the device operates in an overheat mode boiling of water at the sensor surface prevents operation at less than saturation pressures, which correspond to a depth of $34 \mathrm{~m}$ at the temperatures we were operating in.

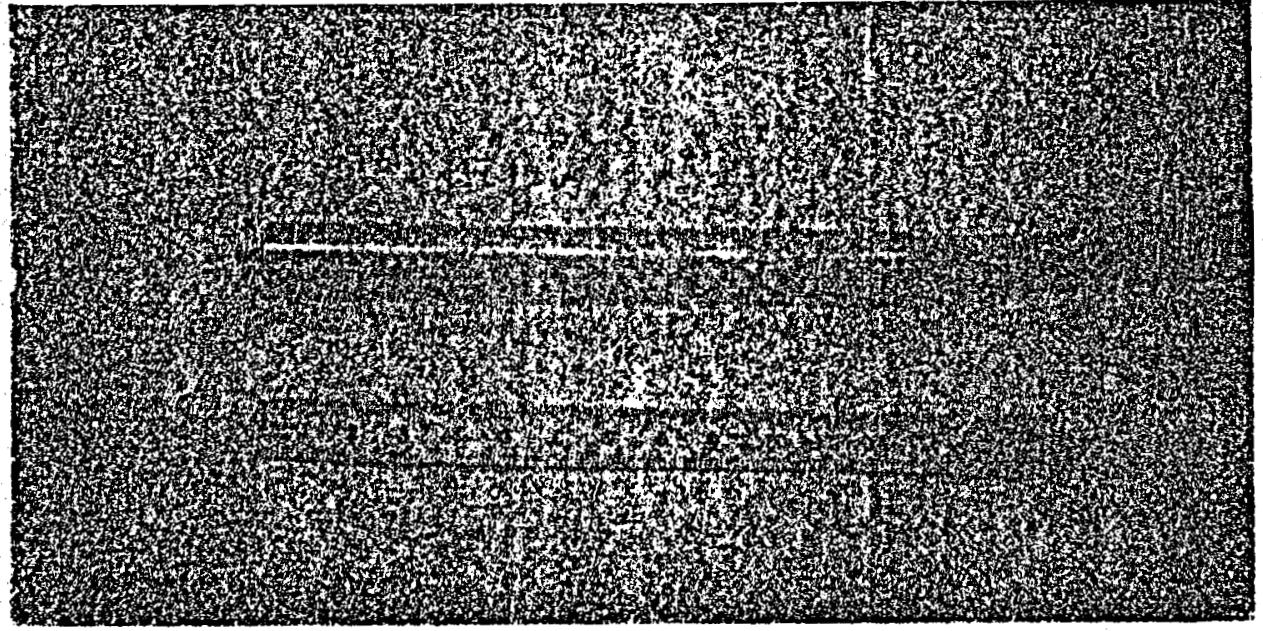

Figure 5. Hot Film Anemometer Probe

Velocities measured in cased wells with no DHE installed ranged from 9 to 14 $\mathrm{cm} / \mathrm{sec}$ with the average about $12 \mathrm{~cm} / \mathrm{sec}$, or approximately 2.5 times those measured with the spinner in the same wells. These higher valued correspond closely with results of analytical models to be discussed later.

Attempts to measure vertical and horizontal flows in the perforation zones were not altogether successful. Apparently, there is significant turbulence due to the long narrow perforations. Vertical flows were stable in regions above and below the perforations but showed significant fluctuations in the perforated zones. Horizontal velocities indicated were near the lower limit of detection and below the limits of the calibration facility used to calibrate the anemometer.

Recently, the use of a highly fluorescent dye has been tried as an economical method of obtaining circulation flow rates. Only one experiment has been conducted 
in a well with a nonoperating DHE. Five grams of Rhodamine 6-C were mixed with $10 \ell$ of water which was quickly inserted at the perforation zone through a garden hose. Samples of water were taken from the perforation zone at timed intervals by means of a standard "thief" sampler and the samples analyzed later in the laboratory. At least 4 peaks in concentration could be detected indicating 4 cycles of circulation before the dye was completely mixed in the well water.

Rhodamine 6-G is harmless in the concentrations used, and can be readily detected by ultraviolet fluorescence to less than 3 parts per 10 billion. Refinement of the method using a small continuous sampling pump is planned.

\section{Energy Extraction Rates For Conventional DHEs}

Although it has been known for many years that the use of a perforated casing somewhat smaller than the wellbore increased the output of a DHE, there was no information about the relative improvement or the mechanisms that provide the increase. In order to quantify the improvement, obtain information with regard to energy balances within the well, and provide data for model evaluation, tests were run on DHEs installed in a well both before and after casing installation.

A DHE consisting of 20 lengths $(128 \mathrm{~m})$ of $5 \mathrm{~cm}$ black iron pipe was installed in a recently drilled, but uncased, $65.5 \mathrm{~m}$ deep, $30 \mathrm{~cm}$ diameter well. The temperature profile is shown in Figure 6 , and vertical velocities measured with the spinner are shown in Figure $7^{1}$. Tests were run with $.76 \mathrm{l} / \mathrm{sec}, 1.30 \mathrm{l} / \mathrm{sec}$, and $1.89 \mathrm{l} / \mathrm{sec}$ of $21.1^{\circ} \mathrm{C}$ water flowing through the DHE. DHE output temperature (LWT) and temperatures at various depths vs. time are shown in Figure 8.

After testing the uncased well, the DHE was removed and a $20.3 \mathrm{~cm}$ dlameter perforated casing was installed. After casing, the temperature was nearly isothermal with depth and vertical velocity had increased significantly: (see Figures 6 and 7)

The DHE was installed in the well exactly as before, and tests run at flows of $.74 \mathrm{l} / \mathrm{sec}$. $1.4 \mathrm{l} / \mathrm{sec}$, and $2.6 \mathrm{l} / \mathrm{sec}$. Temperatures at the same depth as the uncased test vs. time are shown in Figure 9.

1 The temperatures indicate that the convection cell is flowing downward inside the casing, and that even though the temperatures in the lower por-

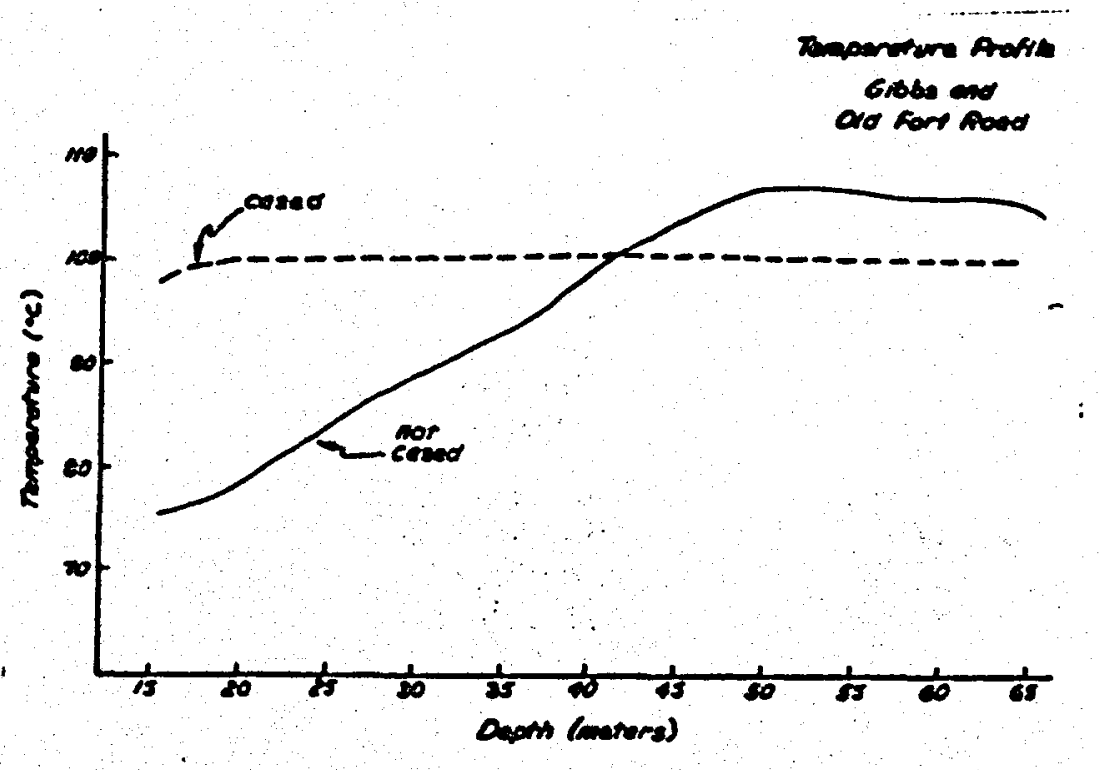

Figure 6. tion of the well are lower and the flow through the DHE is doubled, the temperature of the water leaving the DHE (LWT) is higher. Energy balance calculations show that at elapsed time $130 \mathrm{~min}$., approximately $15 \mathrm{l} / \mathrm{sec}$ are circulating in the convection cell, with about $25 \%$ of that being new hot water from aquifer or about a 258 mixing ratio.

1 These velocities are now known to be low by a factor of nearly 3, but do show relative increases in the cased vs. uncased well. The reason for the Indlcated increase in velocity: with depth is not known. 
Figure 10 shows the energy extraction rates achieved from both the cased and uncased well tests. As expected, the DHE in the cased well was able to produce a significantly higher output than the cased well. At the highest output, DHE energy extraction from the cased well was 175 percent of that of the cased well, about $500 \mathrm{~K} \mathrm{~W}$. However. it must be remembered that energy production would not be that high in the normal mode of operation since the inlet temperature for the test was lower than it would usually be and the $\Delta T$ across the DHE was $63^{\circ} \mathrm{C}$, much more than in usual operation.

Observation of the well water temperature at several depths inside the casing reveal that with sufficient cooling, the convection cell reverses direction going down the inside of the casing and up the outside-opposite of when there is no DHE installed or when loads are very low.

A multi-tube heat exchanger (see Figure 11) was designed utilizing the mathematical model developed, to equal the output and flow resistance of the hair-pin type illustrated earlier. The multi-tube DHE is more economical to install in shallow wells with high static water levels since it can be installed with lighter equipment and has a high output for its short $(6.8 \mathrm{~m})$ length so does not require drilling beyond the hot aquifer when the aquifer is near the surface.

Testing of the multi-tube design was started in June, 1978. On one test at a flow rate of $1.7 \mathrm{l} / \mathrm{sec}$ through the DHE output, was $380 \mathrm{KW}$, with $13 \mathrm{l} / \mathrm{sec}$ of convection cell circulation.

$$
\text { Modeling of Well and DHE }
$$

Analytical models of the cased well with and without a DHE were made.

A differential equation model for the cased well without a DHE was made to determine if thermo syphoning between the inside and outside of the casing due to 
to the temperature gradient of the wall is sufficient to account for the large observed circulation rates. The model developed is quite sensitive to several assumed variables: roughness of the well wall, wall temperature gradient, exact well diameter, and time (because of conduction to the ground), but for reasonable values of these, predicts flows around those observed.

The model for the cased well was extended to include a DHE with flow inside the casing downward. For this model, the wall temperature gradient and time have very little influence, so the main variables are well wall roughness and well diameter. Figure 12 shows the model results for the "standard" and variations of the roughness and well diameter about the "standard" values together with experimentally obtained values.

\begin{tabular}{|c|c|}
\hline \multicolumn{2}{|c|}{ "Standard" Well and DHE Variables } \\
\hline $\begin{array}{l}\text { eneral Characteristics } \\
\text { Well Diameter } \\
\text { DHE Tube Diameter } \\
\text { Static Water Level } \\
\text { Perforation Levels }\end{array}$ & $\begin{array}{l}=0.254 \mathrm{~m} \\
=0.060 \mathrm{~m} \\
=14 \mathrm{~m} \\
17 \text { to } 22 \mathrm{~m} \text { and } \\
57 \text { to } 65 \mathrm{~m} .\end{array}$ \\
\hline Temperature at Bottom of Well & $100^{\circ} \mathrm{C}$ \\
\hline $\begin{array}{l}\text { tandard Parameter Sets: } \\
\text { Casing Diameter } \\
(D / e)_{0} \text { (1/Relative roughness of well wall) }\end{array}$ & $\begin{array}{l}=0.203 \mathrm{~m} \\
=100\end{array}$ \\
\hline Length of cased well & $=50 \mathrm{~m}$. \\
\hline
\end{tabular}

Comparison of the "standard" model predictions and the experimental results Illustrates how well the model predicts energy extraction rates, within about 158, for what are felt to be reasonably estimated parameters. Consequently, the authors feel that thermo syphoning is the major mechanism of heat transfer in wells.

A variable which the differential equation model discussed above neglects is the effect of any mixing of cold fluid at the bottom of the well with warm (new) fluid that goes up the outside of the casing. It is believed that this is one of the main reasons the differential equation model predicts extraction rates lower than those observed-particularly at high extraction rates where the fluid going down the inside of the casing would be cooler.

In order to account for the mixing, and since the differential equation model showed some nonlinearities, could for most purposes be neglected, a simplified network model was developed. 
The DHE-wellaquifer system is modeled as a network with two types of flow: fluid flow (which also transports thermal energy). and heat flow (conduction). Nodes are connected by paths through which fluid flows and these paths connected by heat flow paths. (see Figure 13.)

Application of the network modeling to the well tested with the conventional hair-pin DHE shows closer agreement with experimental results, particularly in the higher output regions. (see Figure 14) As noted earlier.

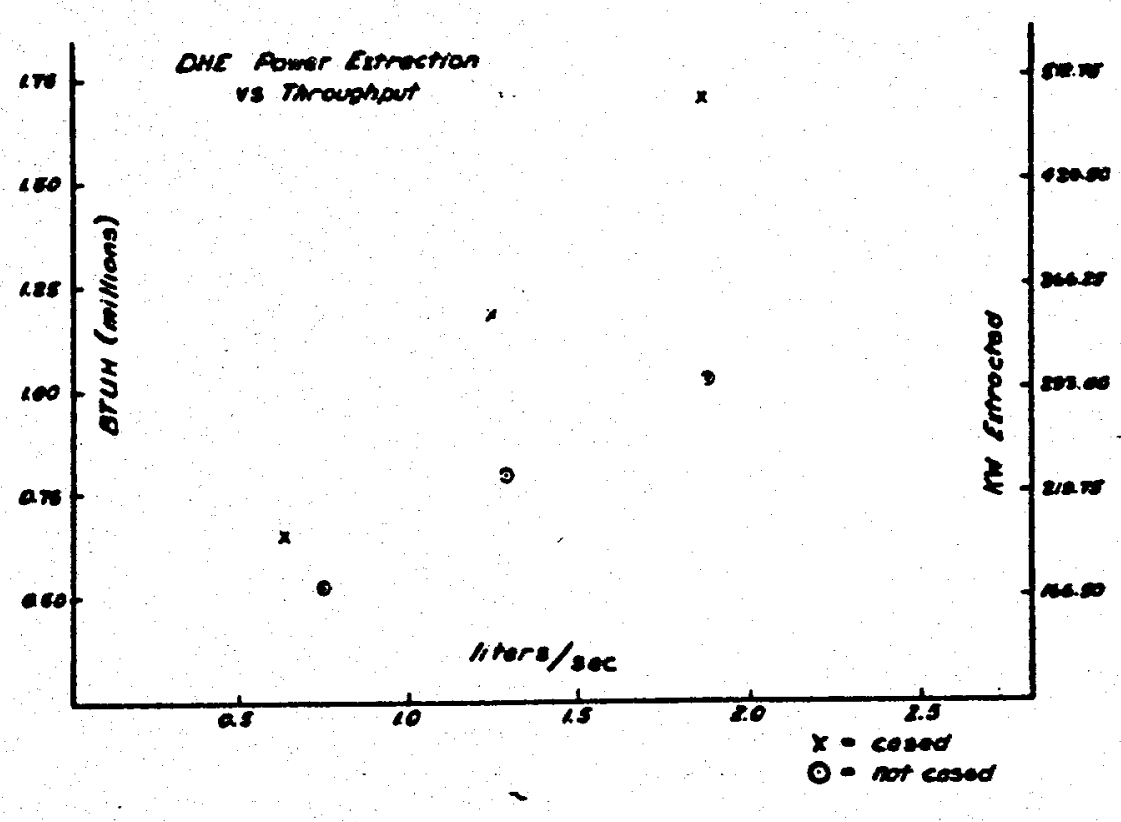
this model was used to design short multi-tube DHEs and testing of these was started in June, 1978.

Although only preliminary results are available at this time, indications are that the model predicts output within about 10 percent at moderate extraction rates, and mixing ratios below .5 if the mixing ratio is known. Mlxing ratios can be determined from energy balance calculations using temperatures measured at various points in the well and DHE input and output temperatures and flow rates. These can be somewhat verified by flow velocity measur ements made with the hot film anemometer. Figure 15 shows the location of measurement points.

The present models appear to be fairly accurate in the range for which they have been experimentally verified. The authors feel that while it must be recognized that there is some uncertainty due to the assumed variables, the models developed do allow the effect of design variables or design constraints of specific applications to be evaluated. In particular, the mixing ratio In the network model is difficult to predict at this time. Experience shows that this ratio may vary significantly in different wells, and is probably directly related to permeability, but this has not been verified experimentally at this time. Some information on permeability in the wells tested is expected to be available at a later date, and it is hoped that a correlation can be developed.

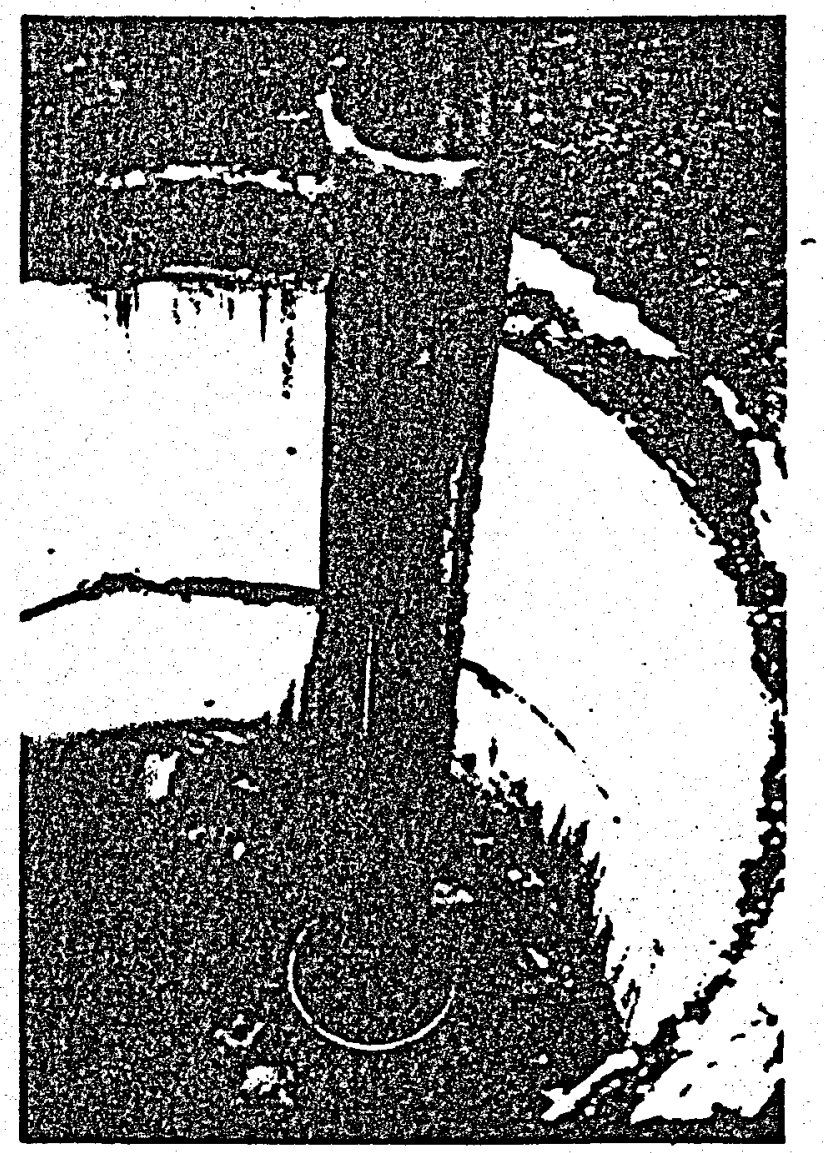

Figure 11. 
Parametric analysis of the influence of design variables and constraints have been conducted. The variables considered include:

(i) well characteristics, length, diameter, casing diameter, and source temperature;

(ii) heat exchanger design variables, diameter, number of loops, and length;

(iii) heat exchanger fluid (water) variables, mass flow rate and inlet temperature.

The many results available from this analysis are too numerous to present here but will be available soon from the authors or through another publication. Here, they will be treated in a qualitative sense only.

In general, increases in source temperature and well diameter both provide increased energy extraction rates. The length $L$ and well casing diameter on the other hand both have an optimum value where the maximum energy extraction

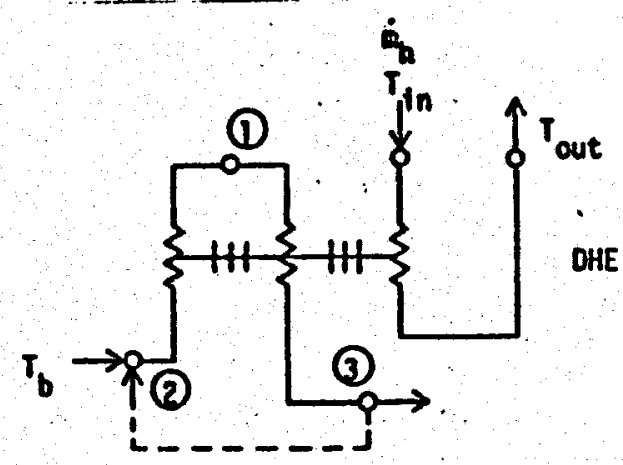

Network Model with Recirculation.

Figure 13.

rate occurs. The influence of the casing diameter is particularly interesting: in usual appllcations where the well is $0.254 \mathrm{~m}$ in dlameter the casing is $0.203 \mathrm{~m}$; the parametric analyses show that roughly $50 \%$ higher heat transfer rates can be expected with a smaller casing. The length is not nearly as controllable as the casing diameter since it is dictated to a large extent by the depth of the hot water strata. However, in some instances locating the top perforations at a lower level could prove beneficlal.

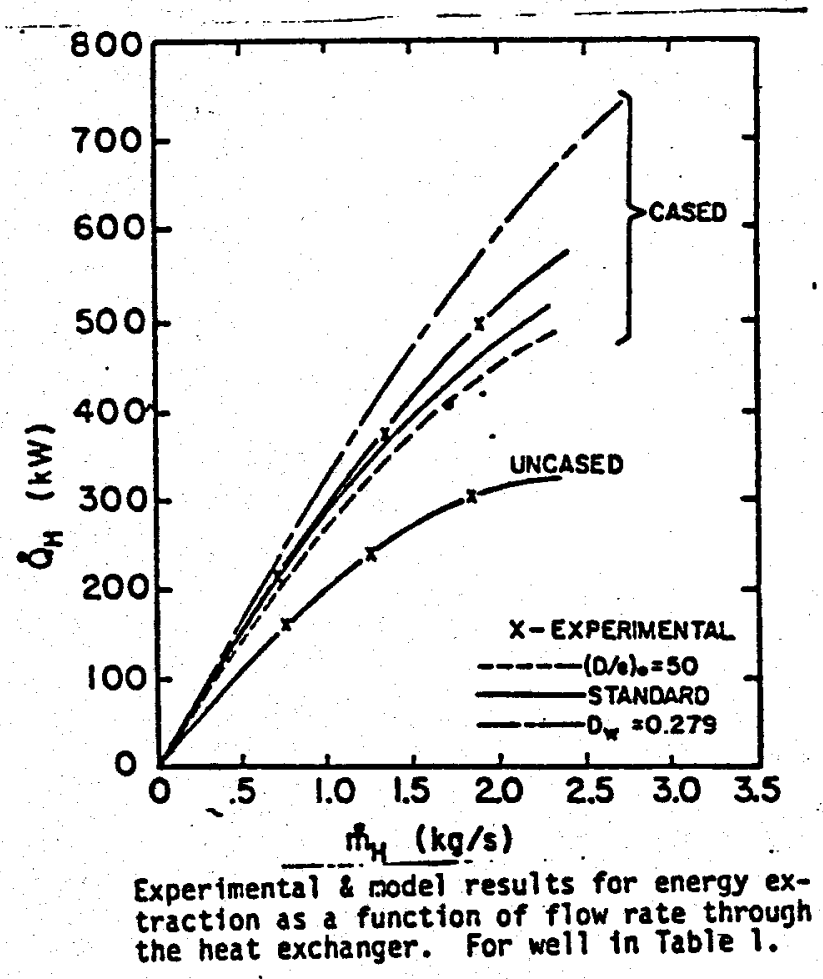

Figure 12.

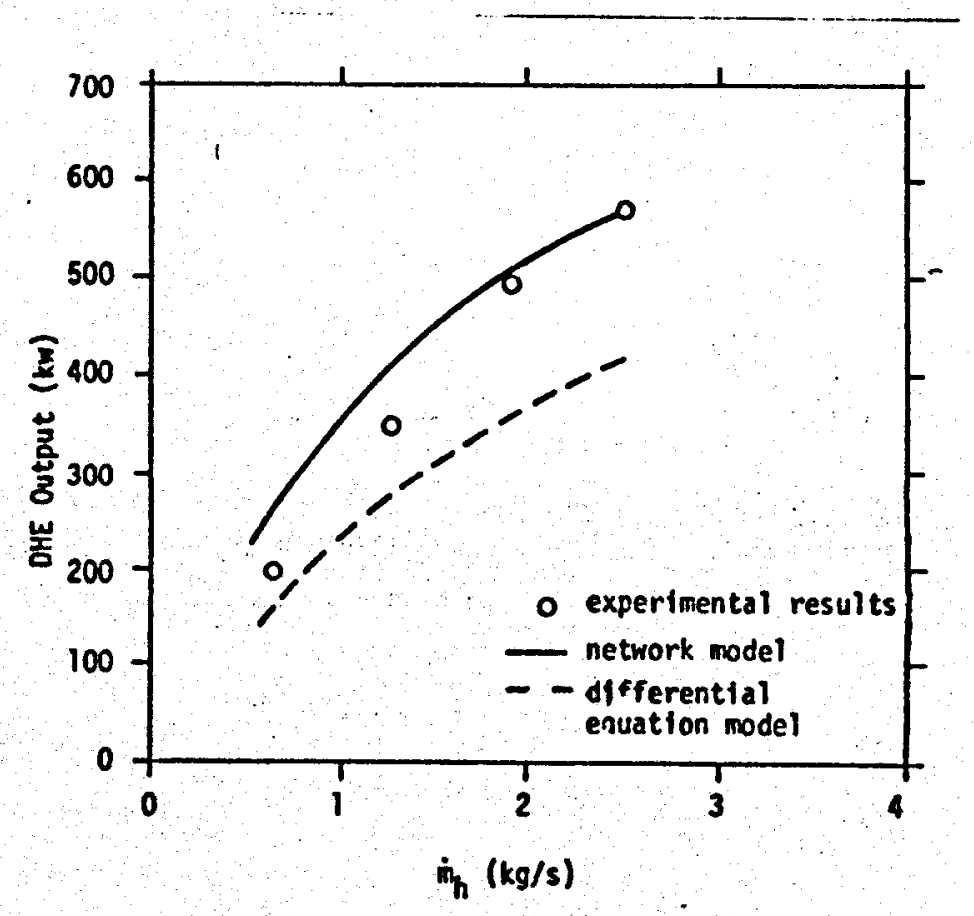

Figure 14. Experimental Results Model Predictions 
The influence of the heat exchanger design variables is harder to generalize since there are trade-offs between tube diameters and number of loops in parallel. For the heat exchanger length (less than total length of the well), however, changes are almost directly proportional to changes in the energy extraction rate.

Increasing mass flow rate through the heat exchanger increases the energy extraction rate, but also increases pressure drop and decreases outlet temperature. Increased pressure drops will require larger circulation pumps and lowered outlet temperatures will affect process design. Decreasing the inlet temperature markedIy increases the energy extraction rate but also decreases the outlet temperature.

\section{Economics}

The economics are difficult to generalize and each particular installation must be indi-

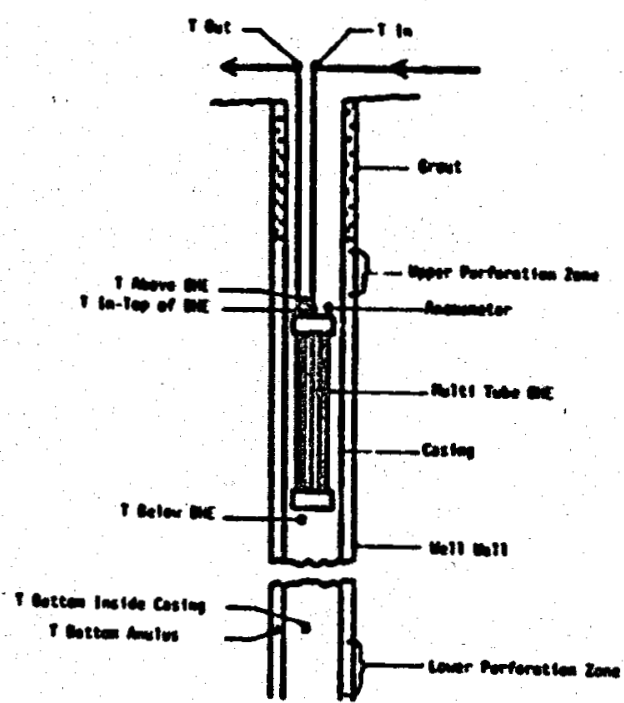

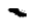

Figure 15. vidually analyzed. The main advantages of the DHE and the major factors in the economics of any installation are the elimination of surface discharge or reinjection when using the DHE, and elimination of corrosion and scaling in heat exchange equipment. The degree of importance of these factors depends on water quality, which will vary from site to site, or may be set by legislation.

Surface discharge may be prohibited due to high concentrations of heavy metals, boron, fluorine, arsenic, $\mathrm{H}_{2} \mathrm{~S}$, or other chemicals, or thermal pollution of surface waters. Corrosion or scaling of heat exchange equipment may be caused by high concentrations of sillcates, carbonates, calcites, chlorine, sulphates, $\mathrm{H}_{2} \mathrm{~S}$ and others. When these constituents are present, either reinjection or treatment are indicated.

Reinjection requires a reinjection well and perhaps a reinjection pumping system. In the shallow aquifers for which the DHE seems best suited, reinjection wells usually will be of the same depth and require at least partial casing since the water should (and may be required by law) be reinjected into the same aquifer from which it was taken. Since the reinjection well should be some distance from the production well, there is also a requirement for additional land.

Corrosion and scaling, while not usually a major problem in low temperature applications, may require either treatment facilities whlch are always expensive, more expensive fabrication materials or frequent replacement of components.

Figure 16 shows the results of generalized economic comparisons of DHEs with surface heat exchangers. The desirability of one or the other is very much dependent on peak energy use and well depth. Table 2 lists some of the major assumptions used to complle Figure 16. 
TABLE

Major Assumptions for Economic Analysis of DHE and SHE Systems.

General:

Source Temperature

Minimum Usable Temperature

Interest Rate

Drilling Cost

Casing Cost

Well Life

$100^{\circ} \mathrm{C}$

$70^{\circ} \mathrm{C}$

78

$\$ 1.75$ per in. dia. per

$\mathrm{ft}$. depth

$\$ 9.00 \mathrm{ft}$.

50 years

Downhole Heat Exchanger:

Heat Exchanger Life 20 years

Casing Depth

Depth of well

Surface Heat Exchanger:

Pump Life

Heat Exchanger Life

Casing Depth

Pump Bowl Depth

Reinjection Well Depth

Production Well Capacity

Operation and Maintenance

- 15 years

15 years

$1 / 3$ well depth

$1 / 3$ well depth

Same as production well $500 \mathrm{gal} . / \mathrm{min}$. 108 of yearly costs

Acknowledgement and Disclaimer

This work has been supported under U. S. Energy Research and Development Administration (now Department of Energy) Contract number EY-76-5-06-2429. As such, it was prepared as an account of work sponsored by the United States Government. Neither the United States nor the United States Department of Energy. nor any of their employees, nor any of their contractors, subcontractors, or their employees, makes any warranty, express or implied, or assumes any legal liability or responsibility for the accuracy, completeness or usefulness of any information, apparatus, product or process disclosed, or represents that its use would not infringe privately-owned rights.

References

(1) Culver, G.G., J. W. Lund and L. S. Svanevik, "Klamath Falls Hot Water Well Study, "UCRL-13614, 1974, Lawrence Livermore Laboratory, Livermore, California.

(2) Lienau, P. J., and J. W. Lund, "Utilization and Economics of Geothermal Space Heating in Klamath Falls, Oregon." 


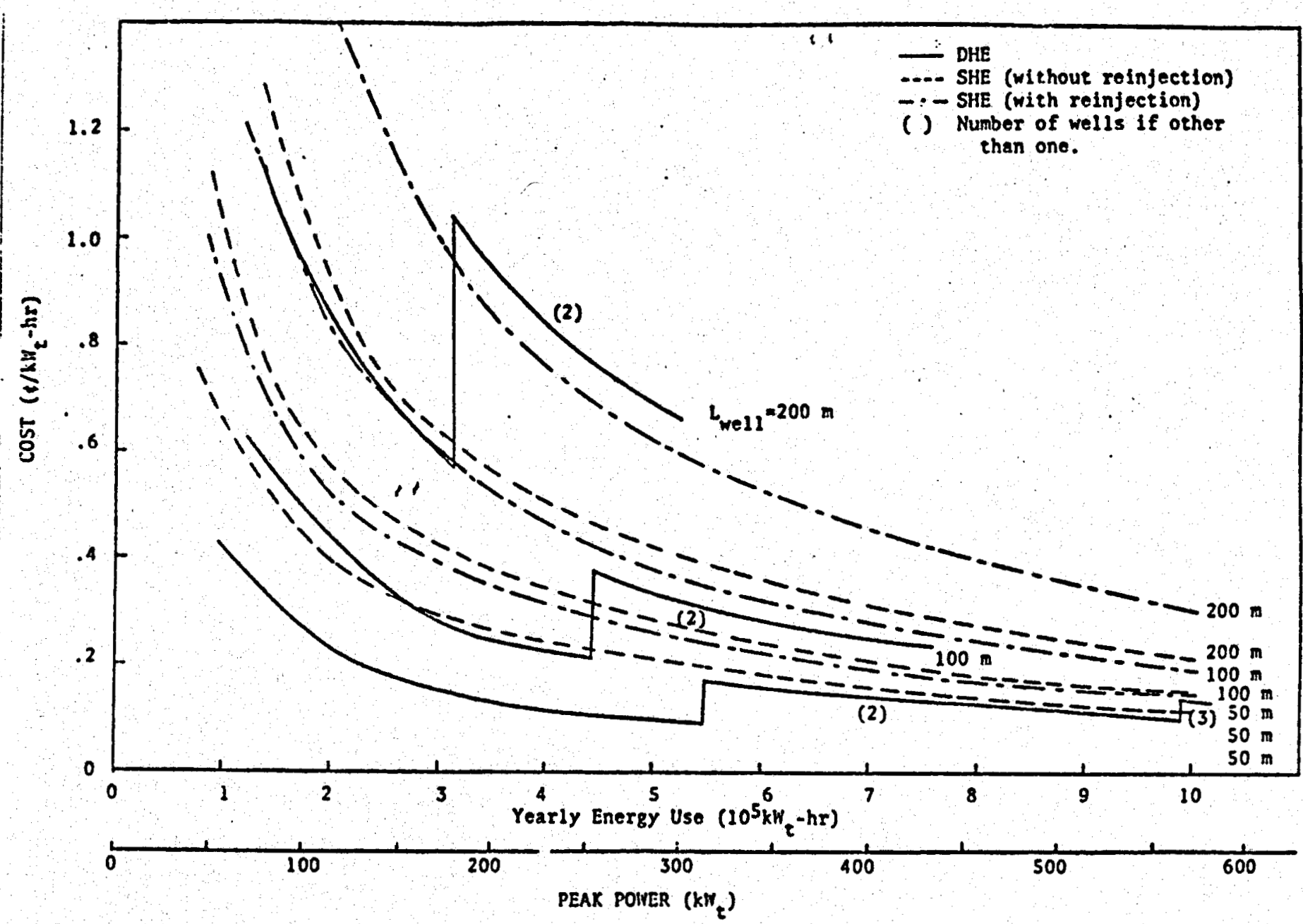

Figure 16. Economic comparisons of Downhole Heat Exchange (DHE) Systems with Surface Heat Exchange Systems as a function of peak power requirement (and yearly energy use at 0.2 load factor and well depth. 